\title{
ДИСКУССИИ
}

DOI: https://doi.org/10.15688/jvolsu2.2020.1.15

UDC 811.161.1'37

Submitted: 02.07.2019

LBC 81.411.2-002

Accepted: 06.12.2019

\section{PSYCHOSEMANTIC EXPERIMENT AS A TOOL FOR OBJECTIFICATION OF THE DATA FOR THE WAYS OF REPRESENTING SYNONYMY IN A MODERN RUSSIAN LANGUAGE ${ }^{1}$}

\author{
Irina V. Erofeeva \\ Kazan Federal University, Kazan, Russia \\ Valery D. Solovyev \\ Kazan Federal University, Kazan, Russia \\ Venera R. Bajrasheva \\ Kazan Federal University, Kazan, Russia
}

\begin{abstract}
The recently created RuWordNet thesaurus reflects hierarchical, primarily synonymous, relations in the vocabulary so that it is built from a set of synsets. In this paper, we applied the method of a comparative analysis: we compared the data of classical dictionaries of Russian language synonyms, RuWordNet thesaurus and the results of a students' poll. The students represent two areas of specialization: linguistic and nonliguistic. As a result of the psychosemantic experiment, we specified the criteria for the distribution of lexical units among synsets. We referred to them cognitive, semantic, stylistic and quantitative criteria. The quantitative method made it possible to determine the fixation frequency of synonyms for the stimulus word in the respondents' minds. The results of the experiment showed that the most adequate principle, implemented in verbal and cogitative activity by the identifying of the synonymic chains, is a pragmatic one. It reveals itself in the possibility of the interchange of similar in meaning words in different contexts. The research results contain recommendations on the systematization of linguistic information in the RuWordNet thesaurus, aimed at improving the principles of synsets' building. The performed research is aimed at verifying the reflected in RuWordNet data from the point of view of their correspondence to the real idea of native speakers of the synonymic, hyponymic and other system-based relationship in the vocabulary.
\end{abstract}

Key words: RuWordNet, synonyms, synset, psychosemantic experiment, lexicography.

Citation. Erofeeva I.V., Solovyev V.D., Bajrasheva V.R. Psychosemantic Experiment as a Tool for Objectification of the Data for the Ways of Representing Synonymy in a Modern Russian Language. Vestnik Volgogradskogo gosudarstvennogo universiteta. Seriya 2. Yazykoznanie [Science Journal of Volgograd State University. Linguistics], 2020, vol. 19, no. 1, pp. 178-194. (in Russian). DOI: https://doi.org/10.15688/jvolsu2.2020.1.15

\section{ПСИХОСЕМАНТИЧЕСКИЙ ЭКСПЕРИМЕНТ КАК ИНСТРУМЕНТ ОБЪЕКТИВАЦИИ ДАННЫХ О СИНОНИМИИ (НА МАТЕРИАЛЕ РУССКОГО ЯЗЫКА) ${ }^{1}$}

\author{
Ирина Валерьевна Ерофеева
}

Казанский федеральный университет, г. Казань, Россия 


\section{Валерий Дмитриевич Соловьев}

Казанский федеральный университет, г. Казань, Россия

\section{Венера Рустамовна Байрашева}

Казанский федеральный университет, г. Казань, Россия

Аннотация. Объектом изучения стал недавно созданный тезаурус RuWordNet, который отражает иерархические отношения в лексике (прежде всего синонимические) и состоит из совокупности синсетов. Исследование нацелено на верификацию данных, зафиксированных в RuWordNet, с точки зрения их соответствия реальному представлению носителей языка о синонимических, гипонимических и прочих системных отношениях в лексике. В статье применен метод сопоставительного анализа: сравнению подверглись данные словарей синонимов русского языка, тезауруса RuWordNet и опроса студентов двух разных направлений специализации - филологического и нефилологического. В результате психосемантического эксперимента уточнены когнитивный, семантический, стилистический, количественный критерии распределения лексических единиц по синсетам. С помощью квантитативного метода определена частотность фиксации в сознании синонимов к слову-стимулу. Показано, что наиболее адекватный принцип, реализуемый в речемыслительной деятельности при выявлении синонимических рядов, - прагматический, предполагающий возможность взаимозамены близких по значению слов в различных контекстах. Даны рекомендации по систематизации лингвистической информации в тезаурусе RuWordNet, которые направлены на усовершенствование принципов построения синсетов.

Ключевые слова: RuWordNet, синоним, синсет, психосемантический эксперимент, лексикография.

Цитирование. Ерофеева И. В., Соловьев В. Д., Байрашева В. Р. Психосемантический эксперимент как инструмент объективации данных о синонимии (на материале русского языка) // Вестник Волгоградского государственного университета. Серия 2, Языкознание. - 2020. - Т. 19, № 1. - C. 178-194. - DOI: https://doi.org/ 10.15688/jvolsu2.2020.1.15

\section{Введение}

В современном языкознании сохраняются сложности в установлении синонимичности слов. Поэтому, «принимая во внимание принципы господствующей ныне антропоцентрической парадигмы, в качестве такой системы отсчета целесообразно избрать речевую деятельность языковой личности» [Ольховская, 2017, с. 97]. В основе синонимии лежат принципы категоризации явлений внеязыковой действительности, их объединения в сознании носителей языка на основании общности денотата или сигнификата. Отличия в категоризации внеязыковой действительности наиболее отчетливо отражаются в лексико-семантической системе языка [Erofeeva, Gimatova, Sergeeva, 2018, с. 54]. При этом ученые говорят о возможности как коллективной категоризации, при которой выделяются более существенные и общие признаки того или иного понятия, так и индивидуальной категоризации, при которой выделяются признаки, объединенные в сознании отдельной личности [Лебедева, 2002, с. 18]. С этим связано несовпадение синонимических рядов в словарях синонимов и сознании отдельных индивидов.

Наличие близкозначных слов является естественным фактом любого языка, и необходимость их лексикографической фиксации возникла давно в связи с причинами как теоретического, так и практического характера. С теоретических позиций взгляды на синонимию различаются, как и принципы представления синонимов в многочисленных словарях.

В качестве базы для исследования были использованы примеры из существующих на сегодняшний день словарей синонимов русского языка (см. список источников и словарей), данные недавно созданного тезауруса RuWordNet, отражающего системные отношения в лексике русского языка, и данные опроса студентов. Цель работы состояла в сопоставлении принципов кластеризации информации в классических словарях синонимов русского языка, тезаypyce RuWordNet и ментальном лексиконе студентов филологических и нефилологических специальностей. Среди респондентов нефилологических специальностей - студенты физики, математики, экономисты и экологи, для которых одним из базовых предметов как при 
вступительных испытаниях, так и в обучении является математика.

Тезаурусы представляют собой разновидность словарей, в которых отражаются особые формы кластеризации лексики по семантическому признаку. В них лексемы зафиксированы в составе синонимических групп, получивших название синсет (англ. synset). В лингвистическом отношении такие группы состоят из квазисинонимов, связанных не только отношениями синонимии, но и паронимии, антонимии, гипонимии, гиперонимии и т. п. Проект WordNet впервые возник в США в 1980-е гг, и в нем отразились более сложные отношения между лексическими единицами языка, чем в словарях [Копотев, 2014; McEnery, Hardie, 2011].

\section{Материал и методы исследования}

В исследовании были использованы лингвистические и психолингвистические методы. Психосемантика, изучая формы существования значения в человеческом сознании, рассматривает картину мира как осознаваемые и неосознаваемые пласты ментальности [Петренко, 2009, с. 58]. При этом картина мира представляет собой структурированную совокупность отношений к воспринимаемым сознанием объектам [Артемьева, 1999, с. 21]. Использование сопоставительного метода позволило сравнить специфику систематизации лингвистической информации в RuWordNet и синонимических словарях русского языка, что дало возможность сравнить принципы построения словарных статьей (синсетов) в них. В процессе исследования применялся психолингвистический эксперимент как важнейший способ верификации созданной лингвистами модели [Леонтьев, 1997, с. 129; Нистратов, Тарасов, 2017]. Поскольку эмпирическое исследование языка строится на анализе его живого функционирования и характера отражения в сознании индивида, данный эксперимент был нацелен на выявление синонимических отношений в языковом сознании с учетом степени близости лексем, их стилистической окраски, иерархических отношений. Семантико-когнитивный метод использовался для уточнения семантического содержания ряда лексических единиц с точ- ки зрения отображения в них свойств реальной действительности.

Важным аспектом разграничения синонимов является их различение по денотату и сигнификату. В случае синонимии по сигнификату полностью или частично совпадают понятия, обозначаемые языковыми знаками. Следовательно, существенным оказывается учет дифференциальных признаков понятий, которые в зависимости от контекстуальных условий могут способствовать сближению соответствующих номинаций и их синонимизации [Гутнер]. Вопрос о принципах отнесенности слова к тому или иному синонимическому ряду остается открытым.

При этом синонимические ряды квалифицируются как полевая структура, ряды с нечеткими границами, отличающиеся неполнотой и незавершенностью [Дударева, 2011]. Это положение подтверждается данными словарей, ассоциативного эксперимента и материалами RuWordNet. Синонимы входят в ассоциативно-вербальную сеть носителей языка, в которой они находятся в различных отношениях как между собой, так и с другими элементами системы [Janda, Solovyev, 2009]. В этих отношениях участвуют гипонимы, гиперонимы, антонимы, омонимы, паронимы и т. д. Границы между ними не всегда четко определимы.

Различие целей и источников выборки материала обусловливает и различие в способах систематизации изучаемых явлений. Так, «классические» словари синонимов русского языка ориентируются на литературные источники, художественные произведения. RuWordNet, coстоящий из совокупности синсетов (набора синонимов), построен по иерархическому принципу и отражает прежде всего такие отношения, как гипоним - гипероним (родовидовые отношения), мероним - холоним (отношения часть - целое) и др. Тезаурус типа WordNet строился на базе РуТез путем разделения единиц на группы синонимов по частям речи [Порождение тезауруса..., 2016, с. 93].

При попытках систематизировать данные явления неизбежен определенный субъективизм. Вопрос в том, какую цель преследует каждый из лингвистов, фиксирующих синонимичные лексемы в словаре или тезаурусе. 
В проведенном нами психолингвистическом эксперименте классифицируются те парадигматические связи, которые возникают в сознании участников в ответ на слово-стимул. В ходе эксперимента двум группам студентов - филологических и нефилологических специальностей (физикам, математикам, экономистам и экологам) было предложено подобрать синонимы к исходному слову без ограничения по количеству. В процессе его проведения возникли и некоторые погрешности, связанные с близостью психосемантического эксперимента к ассоциативному, поскольку опрашиваемые привели не только синонимы, но и ассоциации к представленному слову. Вербальные ассоциации, возникающие в сознании, тесно связаны со значениями, а совокупность множества ассоциативных реакций в эксперименте отражает множество стратегий вербального ассоциирования, которые имеют индивидуальных характер.

Если языковые единицы соотнесены с языковой системой и языковой нормой, то при проведении эксперимента мы имеем дело с психолингвистическими единицами, которые соотнесены с речевой деятельностью и отражают в сознании психофизиологическую речевую организацию личности.

Результаты эксперимента были сопоставлены с данными RuWordNet с целью уточнения объективности способов параметризации отдельных лексических единиц. В частности, для анализа выбраны лексемы, служащие для номинации чувств, мыслительной деятельности, взаимоотношений между людьми, то есть единицы, обладающие широким смысловым объемом и вступающие в большие синонимические ряды.

Поскольку синонимический ряд - это полевая структура, в ней выделяются ядро и периферия. При этом ядро, как правило, совпадает во всех трех множествах: словарях синонимов, RuWordNet и лексиконе студентов.

\section{Результаты и обсуждение}

Перейдем к сопоставительному рассмотрению представления синонимии в этих трех источниках.

1. К словам отвлеченной семантики, обозначающим умственную деятельность чело- века, относится слово мечта. Данная лексема имеет в русском языке многокомпонентный синонимический ряд. Приведем примеры наиболее развернутых рядов синонимов к этой единице в словарях синонимов.

Так, среди рассмотренных лексикографических источников особо выделяется «Словарь русских синонимов и сходных по смыслу выражений» Н. Абрамова, в котором дается наиболее полный синонимический ряд лексемы мечта, состоящий из 19 компонентов: Мечта - мечтание, бредни, грёза, дума, видение, привидение, иллюзия, призрак, причуда, самообман, самообольщение, утопия, фантазия, химера, воздушный замок, игра воображения, сон, бред, несбыточное желание, идеал, надежда, иель (Абрамов, с. 181).

В «Большом синонимическом словаре русского языка» А.Ю. Кожевникова синонимический ряд лексемы мечта состоит из 7 компонентов: Мечта - грёза, мечтание, воздушные замки, химера (книжн.), иель, желание, идея (Кожевников, т. 1, с. 345).

В других словарях количество синонимов к данной лексеме не превышает четырех единиц. Так, в «Словаре синонимов русского языка» под ред. Л.Г. Бабенко: Мечта - грёза, иллюзия, мечтание, фантазия (Словарь синонимов, с. 83).

B RuWordNet к синсету мечта относятся грёза, мечтания, фантазия (см. рис. 1). Сравнивая полученные данные, приходим к выводу, что выделенные как синонимы в этом тезаурусе слова отражаются в словарях синонимов по-разному: слово грёза отмечается в 6 из 9 рассмотренных словарей, мечтания - в 5, а фантазия - в 3. Более подробно картина распределения синонимических лексем к исходному мечта, как и другим проанализированным единицам, представлена в таблицах, размещенных на сайте https://kpfu.ru/kompleksnyj-analiz-struktury-isoderzhaniya-366287.html.

Для уточнения и верификации представленных в двух сопоставляемых источниках данных был проведен психосемантический эксперимент, в котором участвовали 199 студентов (114 студентов филологических специальностей и 85 студентов нефилологических специальностей). Результа- 


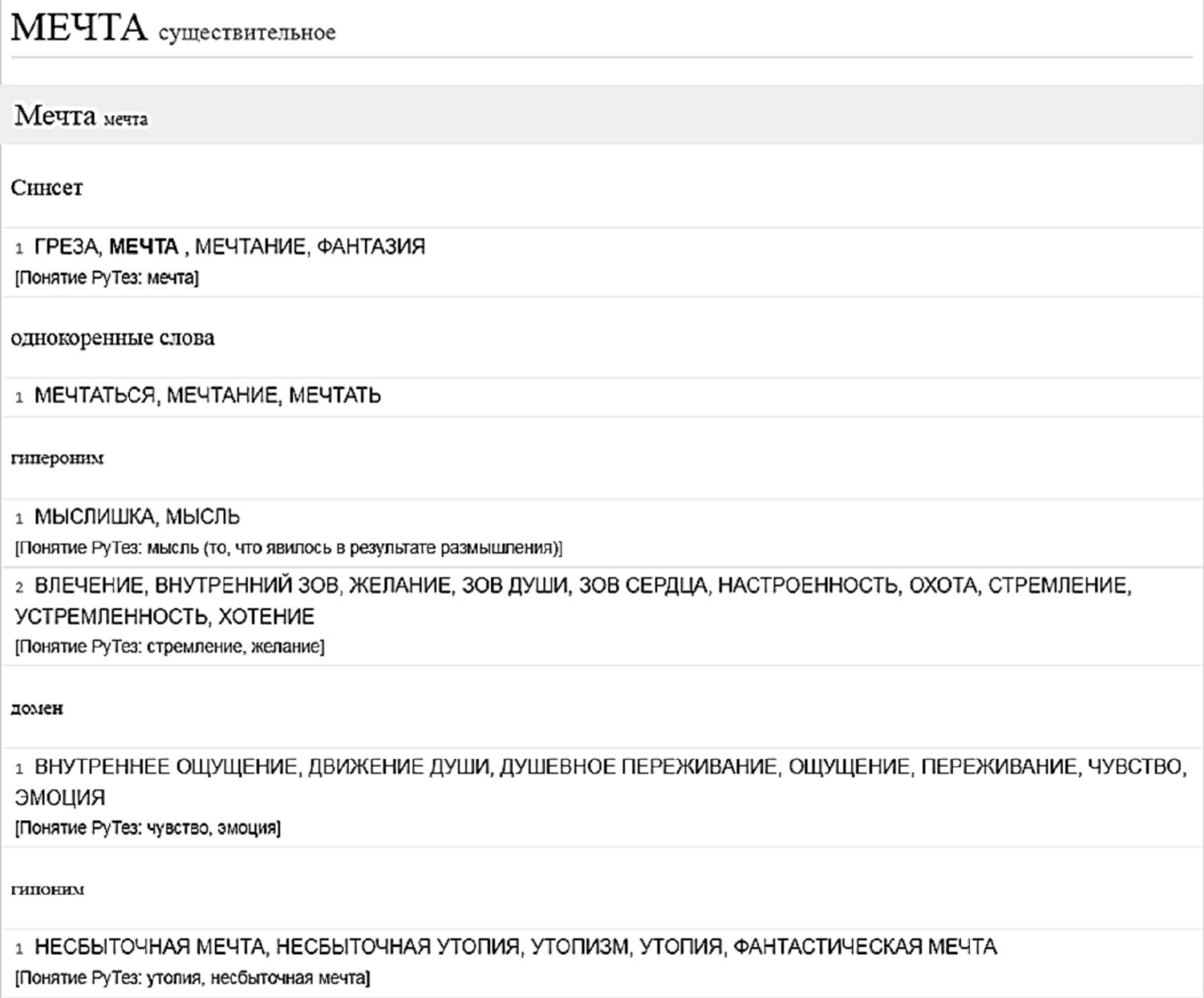

Pис. 1. Синсет мечта в RuWordNet

Fig. 1. Synset dream in RuWordNet

ты эксперимента отражены в таблицах 1 и 2 соответственно.

Итак, фантазия находится на 3-м месте у филологов (23,7 \%), на 4-м - нефилологов $(11,8 \%)$. Лексема грёз $a(b l)$ у студентов филологических специальностей отмечена на 4-й позиции ( $16,7 \%$ ), у нефилологов - на 6-й $(8,2 \%)$; мечтание - на 16-й у филологов

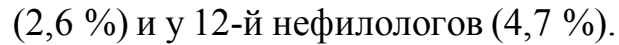

На 1-м и 2-м местах у студентов обоих направлений оказались лексемы желание и иель. B RuWordNet лексема желание представлена среди гиперонимов, то есть слов, выражающих более общее значение, нежели мечта (наряду с влечение, желание, хотение и др.), а слово иель не зафиксировано.

Наиболее частотным из синонимов по данным психосемантического эксперимента (более $50 \%$ ) является слово желание 50,9 \% (58 филологов) и 55,3 \% (47 нефилоло- гов). Следующая по частотности лексема цель - отмечена у 45,6 \% (52 филолога) и 47 \% (40 нефилологов). В словарях синонимов слово цель как синоним слова мечта отмечено лишь дважды.

При сопоставлении толкований слов мечта, желание и цель обнаруживается совпадение в сигнификативной сфере этих лексем. Например, мечта: 1. Нечто, созданное воображением, мысленно представляемое. 2. Предмет желаний, стремлений (Ожегов, Шведова); и одно значение слова желание: Влечение, стремление к осуществлению чего-н., обладанию чем-н. (Ожегов, Шведова). В отвлеченном втором значении ичель означает «предмет стремления, то, что надо, желательно осуществить» (Ожегов, Шведова). Следовательно, слова желание и цель являются синонимами слова мечта во втором значении с которым их объединяют такие компоненты, 
И.В. Ерофеева, В.Д. Соловьев, В.Р. Байрашева. Психосемантический эксперимент

Таблица 1. Результат психосемантического эксперимента со словом мечта среди филологов

Table 1. The result of a psychosemantic experiment with the word dream among philologists

\begin{tabular}{|l|c|l|c|l|c|}
\hline \multicolumn{1}{|c|}{ Синоним } & $\begin{array}{c}\text { Количество } \\
\text { упоминаний }\end{array}$ & \multicolumn{1}{|c|}{ Синоним } & $\begin{array}{c}\text { Количество } \\
\text { упоминаний }\end{array}$ & \multicolumn{1}{c|}{ Синоним } & $\begin{array}{c}\text { Количество } \\
\text { упоминаний }\end{array}$ \\
\hline Желание & 58 & Воображение & 8 & План & 4 \\
\hline Цель & 52 & Иллюзия & 7 & Мираж & 4 \\
\hline Фантазия & 27 & Идеал & 7 & Утопия & 3 \\
\hline Грезы & 19 & Хотение & 5 & Мечтание & 3 \\
\hline Стремление & 14 & Сон & 5 & Видение & 1 \\
\hline Надежда & 11 & Идея & 5 & Дума & 1 \\
\hline
\end{tabular}

Таблица 2. Результат психосемантического эксперимента со словом мечта среди нефилологов

Table 2. The result of a psychosemantic experiment with the word dream among nephilologists

\begin{tabular}{|l|c|l|c|l|c|}
\hline \multicolumn{1}{|c|}{ Синоним } & $\begin{array}{c}\text { Количество } \\
\text { упоминаний }\end{array}$ & \multicolumn{1}{|c|}{ Синоним } & $\begin{array}{c}\text { Количество } \\
\text { упоминаний }\end{array}$ & Синоним & $\begin{array}{c}\text { Количество } \\
\text { упоминаний }\end{array}$ \\
\hline Желание & 47 & Грезь & 7 & Видение & 4 \\
\hline Цель & 40 & Воображение & 5 & Мечтание & 4 \\
\hline Стремление & 10 & Дума & 5 & Вера & 3 \\
\hline Фантазия & 10 & Сон & 5 & Утопия & 1 \\
\hline Надежда & 8 & Иллюзия & 5 & - & - \\
\hline
\end{tabular}

как 'желательность', 'стремление', 'влечение', отражающие направленность на достижение результата.

Некоторые социально-психологические особенности, обусловленные профессиональной ориентированностью получаемого образования участников эксперимента, отразились на количественных данных результатов эксперимента. Исследователи коммуникативной личности филолога отмечают такие ее черты, как выразительность, образность, эмоциональность. «Образность речи филолога в значительной степени является результатом работы с художественным текстом» [Лазуренко, Саломатина, Стернин, 2007, с. 30]. Так, у филологов на 3-м месте располагается лексема фантазия, а у нефилологов на этой позиции находится лексема стремление, и, наоборот, у филологов стремление на 5-й, а у нефилологов фантазия - на 4-й. Более образное мышление филологов, чтение и изучение художественной литературы, формирующие их языковые личности, отражаются на результатах эксперимента: для них мечта ассоциируется с фантазией и грезами, то есть чем-то нереальным, эфемерным. Неофилологи более прагматичны, и у них 3-ю позицию занимает лексема стремление, в се- мантике которой заложено представление о конкретных результатах. B RuWordNet слово стремление относится к гиперонимам лексемы мечта, как и слово желание. Меньшее упоминание студентами слов грёза и мечтание может быть связано с их книжной окраской и редким употреблением в повседневной речи.

Схематично соотношение полученных данных представлено на рисунке 2. Окружности на схеме обозначают следующее: внешняя - максимальное число упоминаний в словарях (8); внутренняя - минимальное число упоминаний в словарях и упоминание в RuWordNet; самая маленькая - отсутствие упоминания в RuWordNet. Вне самого большого круга - гиперонимы в RuWordNet. Bнутри самого маленького круга - гипонимы в RuWordNet.

Как видно на рисунке 2, гипо-гиперонимические связи недостаточно четко отражаются в сознании носителей языка применительно к отвлеченным понятиям. Однако создатели тезауруса все же эти связи фиксируют и такие лексемы, как стремление и желание, попадают за границы круга, то есть являются словами с более широким значением, гиперонимами. При этом «авторы тезауруса подчер- 


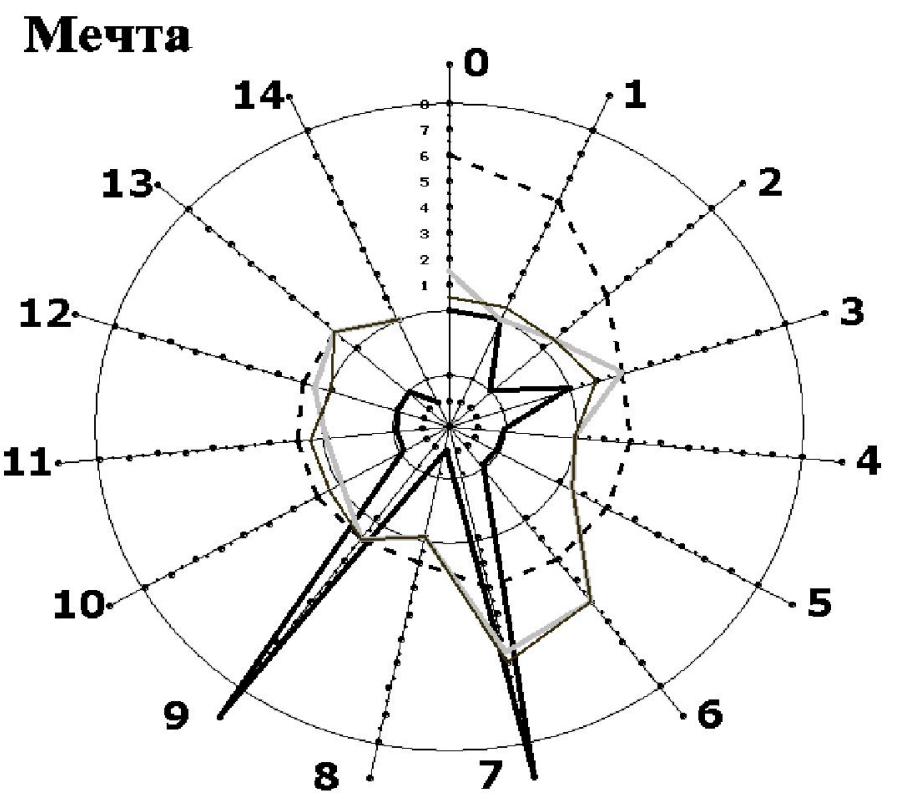

0 - греза;

1 - мечтание;

2 - иллюзия;

3 - фантазия;

4 - химера;

$5-\mathrm{coH}$

6 - цель;

7 - желание;

8 - утопия;

9 - стремление;

10 - дума;

11 - видение;

12 - идеал;

13 - надежда;

14 - утопизм

Рис. 2. Соотношение данных по слову мечта

Fig. 2. Data ratio according to the word dream

Примечание. На рисунке использованы следующие графические обозначения, отражающие соотношения данных по каждой группе источников: пунктирная линия - словарные данные, черная толстая линия RuWordNet, серая линия - результаты опроса студентов-филологов, черная тонкая линия - результаты опроса студентов-нефилологов.

кивают, что на практике различие между синонимией и гипонимией не всегда очевидно» [Лукашевич, 2011, с. 53].

Итак, в словарях и тезаурусе актуализируются такие синонимы рассматриваемого слова, которые указывают на несбыточность, эфемерность, иллюзорность, то есть коррелируют с первым значением слова меч$m a$ - «нечто, созданное воображением, мысленно представляемое», а результаты опроса студентов демонстрируют большую конкретность в восприятии данного понятия - то, что реально осуществимо (ср. со вторым значением слова мечта - «предмет желаний, стремлений»).

Одним из основных принципов объединения слов в синонимические ряды становится возможность взаимозамены в разных контекстах: «Понятие синонимии, используемое разработчиками WordNet, базируется на критерии, что два выражения являются синонимичными, если замена одного из них на другое в предложении не меняет значения истинности этого высказывания» [Лукашевич, 2011 , с. 53]. Если учесть данный принцип выделения синонимов, провозглашаемый со- ставителями ресурса, то в наиболее распространенных контекстах со словом мечта типа $У$ меня есть мечта купить машину или У меня есть мечта получить высшее образование замена возможна именно на синонимы, предложенные студентами, то есть слова желание или цель.

Итак, оба значения лексемы мечта семантически связаны между собой, что отражается в их фиксации в одной словарной статье толковых словарей, однако синонимы к каждому из значений различны, что и определяет различия в словарях синонимов, RuWordNet и результатах эксперимента. $\mathrm{B}$ процессе коллективной категоризации на первый план выходят прагматические аспекты, так как именно они более актуальны в речевой деятельности. Разделение на два синсета, различающихся по идеографическому признаку, позволило бы уточнить приведенные в тезаурусе данные. В существующем синсете слова фантазия, грёзы, мечтания, входят в один ряд с ключевым словом мечта, а сочетания несбыточная мечma и утопия относятся к гипонимам, хотя семантически они очень близки. 
И.В. Ерофеева, В.Д. Соловьев, В.Р. Байрашева. Психосемантический эксперимент

2. Лексемой отвлеченной семантики, связанной с репрезентацией умственной деятельности человека, является воображение.

B RuWordNet это слово представлено двумя синсетами, хотя в словарях синонимов оно отмечается в одной словарной статье. B RuWordNet Воображение 1 в значении «выдумка, вымысел» имеет развернутый синонимический ряд: байка, басня, воображение, вылумка, вымысел измышление, миф, небылица, придумка, россказни, сказка, сочинительство, фантазия (рис. 3). Второй синсет-Воображение 2 в значении «ментальная способность» имеет один синоним фантазия (см. рис. 4). При сопоставлении данных из RuWordNet и словарей синонимов обнаруживается, что наиболее распространенным синонимом к слову воображение является лексема фантазия, которая отмечается в 5 из 8 словарей (слово воображение в них представлено как ключевое), менее частотные синонимы - домысел (в 3 словарях) и выдумка (в 2 словарях).

В обоих синсетах синонимом к слову воображение выступает фантазия. Сопоставление словарных данных с результатами психосемантического эксперимента обнаруживает совпадение мнения разработчиков $\mathrm{RuWordNet,} \mathrm{составителей} \mathrm{словарей} \mathrm{и} \mathrm{реаль-}$ ных психологических ассоциаций. При опросе слово фантазия было отмечено на первом месте с большим отрывом от других синонимов: $61 \%$-у филологов, $66 \%$ - у нефилологов.

В толковых словарях выделяется два значения слова воображение: 1. Способность воображать, творчески мыслить, фантазировать; мысленное представление. 2. Домысел, плод фантазии (разг.) (Ожегов, Шведова). Семантически ассоциированы со вторым значением слова воображение такие лексемы, как домысел - «ничем не подтвержденная догад-

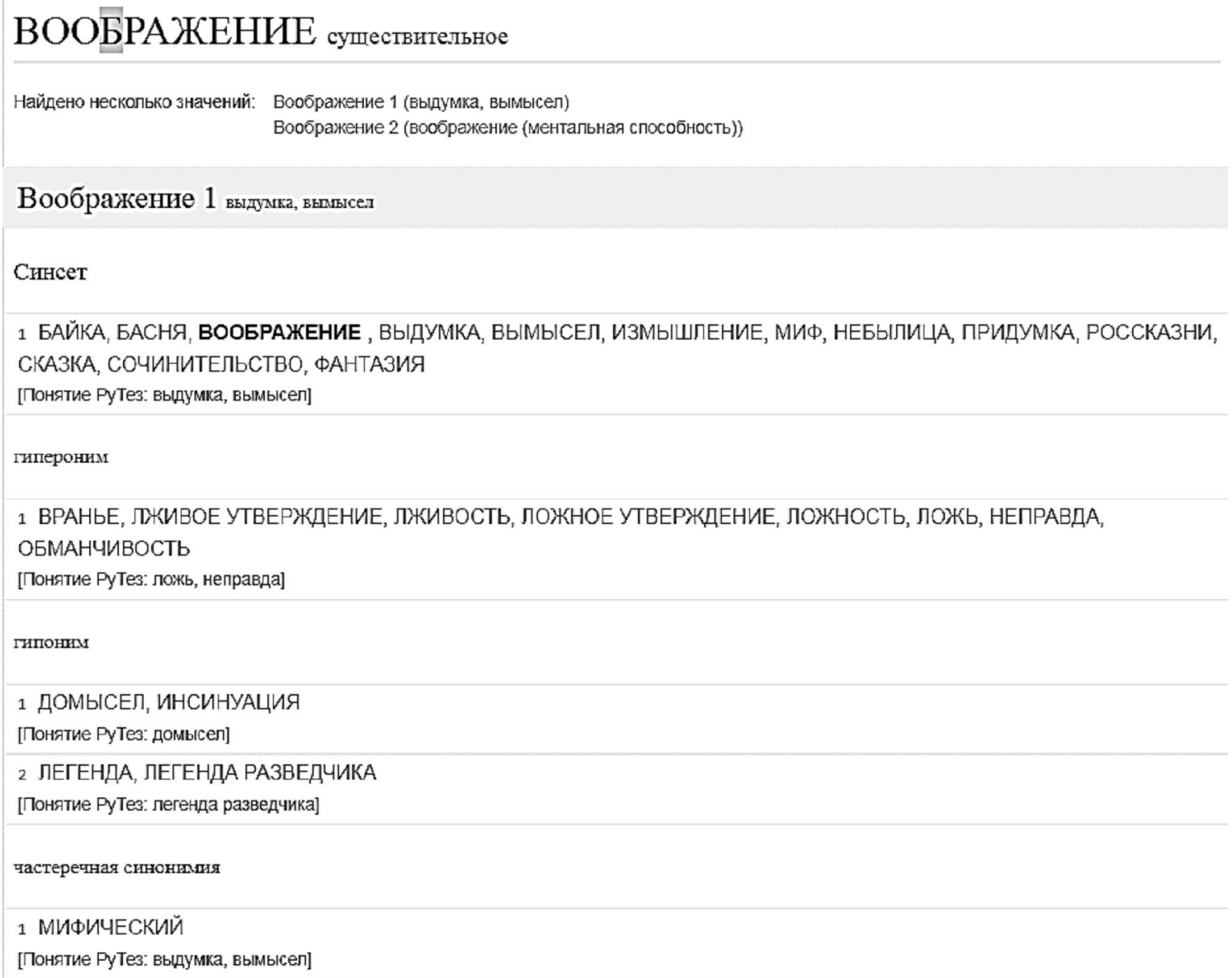

Рис. 3. Синсет воображение 1 в RuWordNet

Fig. 3. Synset imagination 1 in RuWordNet 


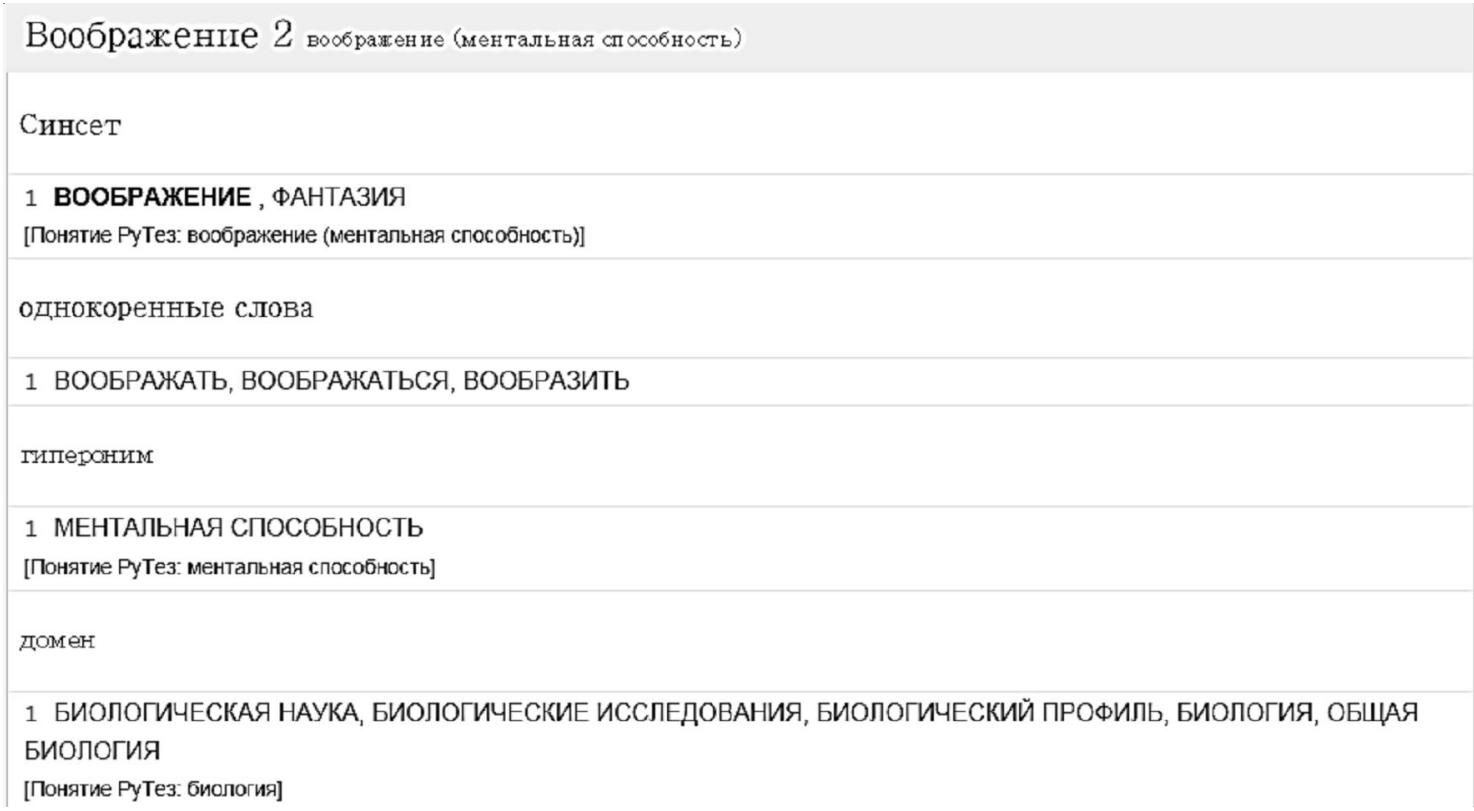

Рис. 4. Синсет воображение 2 в RuWordNet

Fig. 4. Synset imagination 2 in RuWordNet

ка, предположение» (Ожегов, Шведова), вblдумка - «ложь, то, что выдумано» (Ожегов, Шведова), вылыссел - «то, что создано воображением, фантазией» (Ожегов, Шведова).

В ответах филологов домысел отмечается в $4,4 \%$ случаях, нефилологов $-2,4 \%$. B RuWordNet эта лексема представлена как гипоним слова воображение. Однокоренное слово вымысел приводят как синоним слова воображение 9,6 \% филологов и 4,7 \% нефилологов.

Наиболее развернутый синонимический ряд в лексикографических источниках представлен в «Словаре синонимов русского языка» под редакцией Л.Г. Бабенко, причем ключевой лексемой в нем является не воображение, а выдумка: Выдумка - воображение, вымысел, домысел, измышление, легенда, небыль, фантазия, книжн. фантом, разг. басня, разг. небывальщина, разг. небылииа, разг. придумка, разг. россказни, разг. сказка, разг. фантасмагория (Словарь синонимов, с. 165).

В других словарях приводятся единичные синонимы: Воображсение - фантазия (Абрамов, с. 57).

B RuWordNet в синсете Воображение 1 первую позицию занимает слово бай$\kappa a$, отсутствующее в словарях синонимов и опросе нефилологов и лишь один раз отмечен- ное у филологов. В соответствии с данными толковых словарей слово байка во втором (конкретном) значении имеет разговорную окраску: «Побасенка, выдумка, басня (разг.)» (Ожегов, Шведова). Вторым синонимом в рассматриваемом синсете является слово басня, первое значение которого - «стихотворный жанр», второе (конкретизированное, более широкое) - «вымысел, выдумка» (Ожегов, Шведова). В этом же синсете в качестве синонима представлено слово сказка, зафиксированное и в словаре под ред. Л.Г. Бабенко (Словарь синонимов). Первое его значение - «жанр народно-поэтического творчества», второе (более широкое, стилистически маркированное) - «выдумка, ложь (разг.)» (Ожегов, Шведова). В эксперименте слово сказка дважды фиксируется у нефилологов. К этой же группе примыкают и синонимы россказни, сочинительство, миф, основное значение которых связано, скорее, с литературоведческой терминологией (ср. со словами байка, басня, сказка в первом значении), в то время как слово воображение имеет отвлеченную семантику и более широкий смысл. Поэтому в результатах эксперимента данные лексемы практически не получили отражения.

В синсете Воображение 1 отмечается также синоним измышление, одно из его значений - «вымысел, выдумка» (Ожегов, Шве- 
дова). Оно фиксируется только в словаре синонимов Л.Г. Бабенко (Словарь синонимов). Данная лексема относится к малоупотребительным, что подтверждается ее отсутствием в результатах опроса. В ответах филологов и нефилологов отмечается слово мышление, а приставочное образование измышление не фиксируется. Оно изначально обладало приметами высокого стиля - префиксом из- и суффиксом -(е)ние - и имело ограниченное употребление, поэтому включение его в ряд рассматриваемого синсета представляется неудачным.

На наш взгляд, не совсем удачно представлены и гиперонимы к слову воображение в синсете 1: вранье, лживость, ложность, ложь, неправда, обманчивость (рис. 5). Подобные эквиваленты в словарях синонимов не фиксируются. Основное значение слов данного ряда с ключевым ложь - «намеренное искажение истины, неправда, обман» (Ожегов, Шведова).

Синонимы к слову воображение лишены негативной коннотации, в них отражается представление о соотношении мысленного образа с реальностью, в то время как ряд гиперонимов указывает на целенаправленное искажение истины, обман.

По результатам психосемантического эксперимента вторую позицию после синонима фантазия занимает синоним представление, отмеченный практически в одинаковом количестве случаев - $18,4 \%$ у филологов и $17,6 \%$ у нефилологов (в RuWordNet и словарях синонимов данное слово отсутствует), на 3-м месте находится слово выдумка - 9,6 \% филологов и $14,1 \%$ у нефилологов. В таком же количестве случаев филологи отметили и слово вымысел, у нефилологов оно находится на 5-м месте (4,7 \%). Далее последовательность синонимов различается у двух групп опрашиваемых.

У представителей разных специальностей формируется так называемый «профессиональный образ мира», в котором по-особому структурируется семантическая информация, то есть социальные и профессиональные факторы накладывают отпечаток на восприятие и систематизацию представлений в сознании носителей языка. Поэтому у фило-

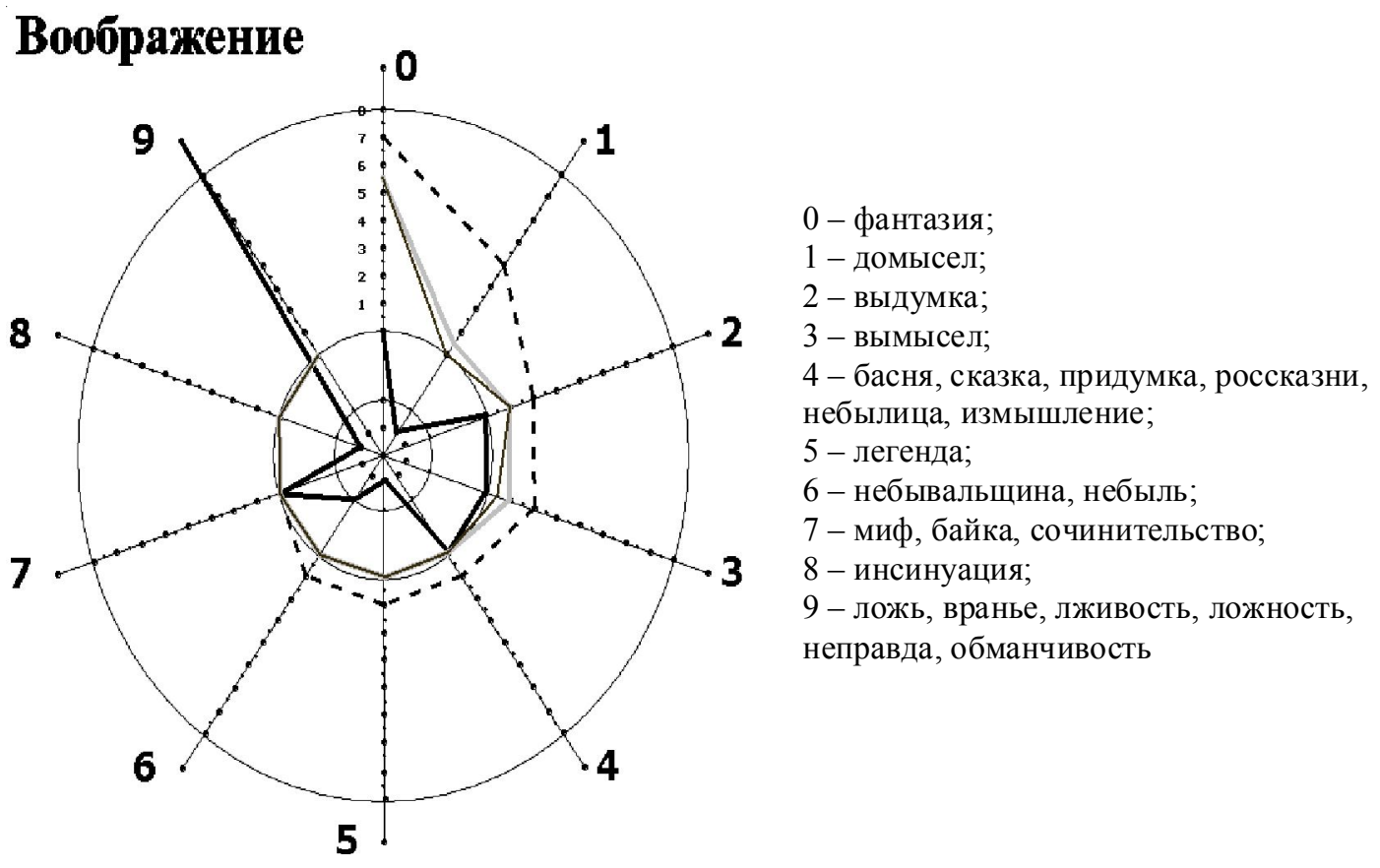

Рис. 5. Соотношение данных по слову воображение

Fig. 5. Data ratio according to the word imagination

Примечание. На рисунке использованы следующие графические обозначения, отражающие соотношения данных по каждой группе источников: пунктирная линия - словарные данные, черная толстая линия RuWordNet, серая линия - результаты опроса студентов-филологов, черная тонкая линия - результаты опроса студентов-нефилологов. 
логов с более развитым творческим воображением и креативностью мышления на 4-й и 5-й позициях оказались лексемы вымысел и мечта, на 6-й - иллюзия, на 7-й - мысль, далее - видение, грёзы, творчество, мечтательность, креативность, причуда и т. д. (табл. 3).

У нефилологов, имеющих, по-видимому, более развитое левое полушарие, отвечающее за аналитическое мышление, математические способности, на 4-й позиции - видение, на 5-й - предположение, на 6-й - причуда, далее - небылица, грёзы, сказка, придумка, домысел, мечтательность, мышление и т. д. (табл. 4).

На рисунке 5 наглядно представлено соотношение данных по лексеме воображение.

3. Слово месть характеризует взаимоотношения людей. В ее репрезентации в RuWordNet и словарях синонимов русского языка наблюдается совпадение: месть входит в один синсет с лексемами мщение, отместка, отмщение (см. рис. 6), как синонимы месть и отмщение фиксируются в 6 из 8 рассмотренных словарей, отместка - в 5 из 8 словарей. Такое распределение, связанное с близостью семантики данных единиц, обусловливается в том числе тем, что они имеют общий корень.

Однако результаты психосемантического эксперимента при рассмотрении синонимов лексемы месть не совпадают с данными лексикографических источников: по итогам опроса у филологов синонимы мщение и отмест$к а$ находятся на 11-12-й позициях, а отмщение - на 16-й; у нефилологов отмщение на 5-й, отместка - на 10-й, мшение - на 12-й позиции. Это свидетельствует о сохранении определенной стилистической маркированности лексем мщение и отмщение, обусловленной их словообразовательным показателем - суффиксом -(e)ни(e), приметой высокого стиля. Слово отместка, напротив, является разговорным. Следовательно, в синсете представлены стилистически маркированные синонимы.

Студенты единодушно на первую позицию поставили слово расплата (26,3\% филологов, 31,8 \% нефилологов). Данный синоним отмечается в единственном из рассмотренных словарей синонимов - словаре Н. Абрамова, впервые изданном еще в 1915 году. В «Толковом словаре русского языка» С.И. Ожегова и Н.Ю. Шведовой (Ожегов, Шведова) значение «кара, возмез-

Таблица 3. Результат психосемантического эксперимента со словом воображение среди филологов

Table 3. The result of a psychosemantic experiment with the word imagination among philologists

\begin{tabular}{|l|c|l|c|l|c|}
\hline \multicolumn{1}{|c|}{ Синоним } & $\begin{array}{c}\text { Количество } \\
\text { упоминаний }\end{array}$ & \multicolumn{1}{|c|}{ Синоним } & $\begin{array}{c}\text { Количество } \\
\text { упоминаний }\end{array}$ & \multicolumn{1}{|c|}{ Синоним } & $\begin{array}{c}\text { Количество } \\
\text { упоминаний }\end{array}$ \\
\hline Фантазия & 70 & Домысел & 5 & Причуда & 2 \\
\hline Представление & 21 & Видение & 5 & Находчивость & 2 \\
\hline Выдумка & 11 & Предположение & 4 & Мечтание & 2 \\
\hline Вымысел & 11 & Грёзь & 4 & Мечты & 2 \\
\hline Мечта & 11 & Творчество & 3 & Мылиление & 2 \\
\hline Иллюзия & 9 & Мечтательность & 3 & Мыслительность & 1 \\
\hline Мысль & 9 & Креативность & 3 & Замысел & 1 \\
\hline
\end{tabular}

Таблица 4. Результат психосемантического эксперимента со словом воображение среди нефилологов

Table 4. The result of a psychosemantic experiment with the word imagination among nephilologists

\begin{tabular}{|l|c|l|c|l|c|}
\hline \multicolumn{1}{|c|}{ Синоним } & $\begin{array}{c}\text { Количество } \\
\text { упоминаний }\end{array}$ & Синоним & $\begin{array}{c}\text { Количество } \\
\text { упоминаний }\end{array}$ & \multicolumn{1}{c|}{ Синоним } \\
\hline Фоличество \\
Фантазия & 56 & Причуда & 3 & Мечтательность & 2 \\
\hline Представление & 15 & Небылица & 2 & Мышление & 2 \\
\hline Вылдмка & 12 & Грёза & 2 & Соображение & 1 \\
\hline Видение & 7 & Сказка & 2 & Творчество & 1 \\
\hline Предположение & 4 & Придумка & 2 & Описание & 1 \\
\hline Вымысел & 4 & Домысел & 2 & - & - \\
\hline
\end{tabular}




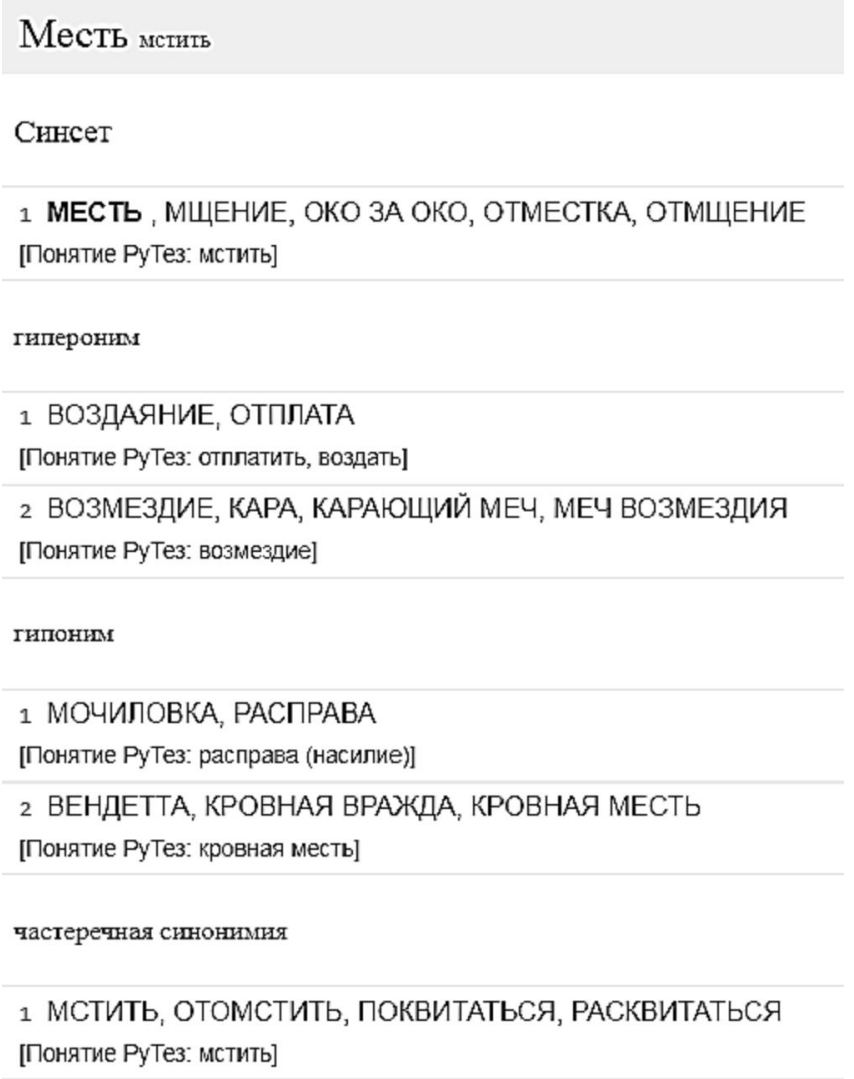

Рис. 6. Синсет месть в RuWordNet

Fig. 6. Synset revenge in RuWordNet

дие (высок.)» для слова расплата является переносным (Ожегов, Шведова). По данным эксперимента, на 2-й позиции находится возмездие (20,2 \% филологов и 27,0 \% нефилологов) (гипероним в RuWordNet), на 3-м месте - наказание (11,4 \% филологов и 23,5 \% нефилологов), на 4-м - злость (11,4 \% филологов и 13 \% нефилологов). Расплата и наказание в RuWordNet не отмечены.

Наиболее развернутый ряд синонимов в лексикографических источниках представлен в словаре Н. Абрамова, причем с отсылкой к слову воздаяние: Месть - вендетта. См.: воздаяние: Воздаяние, вознаграждение, возмещуение, возмездие, кара, месть, награда, отмест$\kappa a$, мздовоздаяние, плата, отплата, расплата, отдача, удовлетворение (Абрамов, с. 53).

В других словарях представлены следующие ряды: Месть - вендетта, мщзение, отместка (разг.), отмщуение (книжн.), отпла$m a$ (Кожевников, т. 1, с. 344)

Месть - вендетта, мщение, отплата, отмщение (книжн.), отместка (разг.) (Словарь синонимов, с. 105).
Месть - мщение, отмщение, отместка (Словарь синонимов русского языка, т. 1, с. 235).

Из примеров видно, что в большинстве словарей на 1-й позиции стоит слово вендет$m a$, хотя оно является заимствованием из итальянского языка и обозначает «жестокая месть». B RuWordNet вендетта, кровная вражда, кровная месть относятся к гипонимам лексемы месть, что представляется оправданным.

B RuWordNet в качестве гипонима слова месть отмечено также слово расправа, значение которого - «насилие над кем-н. с целью отомстить; жестокое наказание» (Ожегов, Шведова) - характеризуется большей акциональностью семантики, чем слово расплата.

Далее результаты эксперимента показывают различия синонимических рядов, построенных филологами и нефилологами: первые приводят слова обида, отплата, ненависть, кара, реванш, злоба (см. табл. 5), вторые - гнев, обида, кара, реванш и т. д. (см. табл. 6).

Рисунок 7 иллюстрирует соотношение данных по слову месть. 


\section{ДискУССИИ}

Таблица 5. Результат психосемантического эксперимента со словом месть среди филологов

Table 5. The result of a psychosemantic experiment with the word revenge among nephilologists

\begin{tabular}{|c|c|c|c|c|c|}
\hline Синоним & $\begin{array}{l}\text { Количество } \\
\text { упоминаний }\end{array}$ & Синоним & $\begin{array}{l}\text { Количество } \\
\text { упоминаний }\end{array}$ & Синоним & $\begin{array}{l}\text { Количество } \\
\text { упоминаний }\end{array}$ \\
\hline Расплата & 30 & Ревани & 8 & Гнев & 4 \\
\hline Возмездие & 23 & Злоба & 6 & Зло & 4 \\
\hline Наказание & 13 & Отместка & 5 & Пакость & 3 \\
\hline Злость & 13 & Мщение & 5 & Вендетта & 3 \\
\hline Обида & 13 & Отдача & 5 & Ярость & 3 \\
\hline Отплата & 11 & Вражда & 5 & Злопамятство & 2 \\
\hline Ненависть & 9 & Pacnрава & 4 & Издевательство & 2 \\
\hline Kapa & 8 & Отмщение & 4 & - & - \\
\hline
\end{tabular}

Таблица 6. Результат психосемантического эксперимента со словом месть среди нефилологов

Table 6. The result of a psychosemantic experiment with the word revenge among nephilologists

\begin{tabular}{|l|c|l|c|l|c|}
\hline \multicolumn{1}{|c|}{ Синоним } & $\begin{array}{c}\text { Количество } \\
\text { упоминаний }\end{array}$ & Синоним & $\begin{array}{c}\text { Количество } \\
\text { упоминаний }\end{array}$ & Синоним & $\begin{array}{c}\text { Количество } \\
\text { упоминаний }\end{array}$ \\
\hline Расплата & 27 & Гнев & 7 & Расправа & 4 \\
\hline Возмездие & 23 & Обида & 7 & Мщение & 2 \\
\hline Наказание & 20 & Кара & 6 & Воздаяние & 2 \\
\hline Злость & 11 & Реванш & 6 & Унижение & 2 \\
\hline Отмщение & 9 & Отместка & 6 & - & - \\
\hline
\end{tabular}

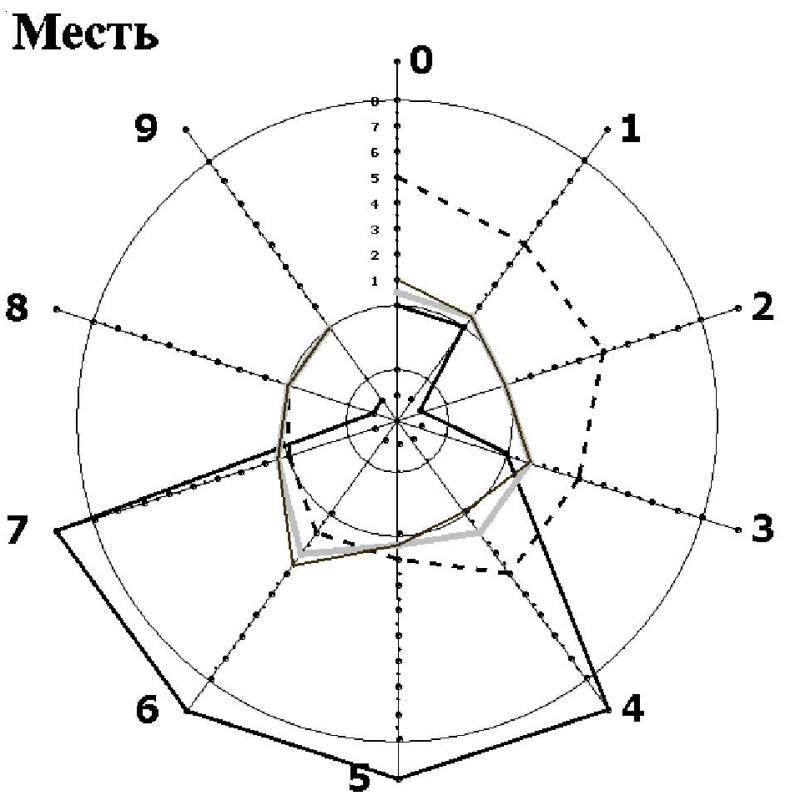

$$
\begin{aligned}
& 0 \text {-мщение; } \\
& 1 \text {-отместка; } \\
& 2 \text {-вендетта; } \\
& 3 \text {-отмщение; } \\
& 4 \text {-отплата; } \\
& 5 \text {-кара; } \\
& 6 \text {-возмездие; } \\
& 7 \text {-воздаяние; } \\
& 8 \text {-мочиловка; } \\
& 9 \text {-расправа }
\end{aligned}
$$

Рис. 7. Соотношение данных по слову месть

Fig. 7. Data ratio according to the word revenge

Примечание. На рисунке использованы следующие графические обозначения, отражающие соотношения данных по каждой группе источников: пунктирная линия - словарные данные, черная толстая линия RuWordNet, серая линия - результаты опроса студентов-филологов, черная тонкая линия - результаты опроса студентов-нефилологов. 


\section{Заключение}

Сопоставительный анализ трех источников (словарей синонимов русского языка, тезауруса RuWordNet и материала, полученного в ходе психосемантического эксперимента среди студентов) позволил выявить совпадения и отличия в рамках отдельных синонимических рядов. Результаты психосемантического эксперимента существенно уточняют характер синонимических отношений между языковыми единицами. Как известно, составители RuWordNet опирались в основном на тексты публицистического стиля, словарей - литературные источники, в то время как в ответах студентов отразилась реальная речевая стихия. B RuWordNet значительное количество представленных лексем носит выраженный разговорный характер, что соответствует общей тенденции стилистического снижения языковых единиц в средствах массовой информации, газетах и журналах. Сопоставление трех синсетов в RuWordNet с данными других лексикографических источников и результатами эксперимента позволило прийти к следующим выводам:

1) количественный и качественный состав синонимических рядов в этих источниках различен и обусловлен комплексом лингвистических и экстралингвистических факторов;

2) деление не синсеты не всегда объективно: так, в один синсет объединены два разных значения слова мечта, хотя целесообразнее было бы разделить их на два синсета; выделение двух синсетов для слова воображение не подтверждается данными эксперимента;

3) иерархическая организация - основной принцип построения корпуса RuWordNet не всегда отражает реальную языковую ситуацию (например, ложь не является гиперонимом к слову воображение);

4) в синсетах не даются пометы стилистического характера, поэтому единицы рядов синонимов, гипонимов и гиперонимов могут восприниматься пользователями как стилистически однородные, однако это противоречит языковой реальности.

Предпринятое исследование имеет целью верификацию данных, отраженных в RuWordNet, с точки зрения их соответствия реальному представлению носителей языка о синонимических, гипонимических и других системных отношениях в лексике. Тезаурусы, построенные по тематическому принципу, имеют задачу не только облегчения подбора синонимов, но и констатации иерархических отношений между группами синонимов - синсетами. Данные психосемантического эксперимента могут быть учтены при внесении поправок в создаваемые и существующие синсеты RuWordNet, так как эта система является открытой и может подвергаться корректировке.

\section{ПРИМЕЧАНИЕ}

${ }^{1}$ Исследование выполнено при финансовой поддержке РФФИ (грант № 18-00-01238) и Правительственной программы повышения конкурентоспособности Казанского федерального университета (государственное задание № 2.8303.2017/8.9).

The reported study was funded by RFBR, grant no. 18-00-01238, and the Government program for improving the competitiveness of Kazan Federal University, state task no. 2.8303.2017/8.9.

\section{СПИСОК ЛИТЕРАТУРЫ}

Артемьева Е. Ю., 1999. Основы психологии субъективной семантики / под ред. И. Б. Ханиной. М. : Наука : Смысл. 349 с.

Гутнер Г. Б. Синонимия // Гуманитарная энциклопедия: Концепты. URL: https://gtmarket.ru/ concepts/7061 (дата обращения: 29.05.2019).

Дударева Я. А., 2011. Особенности семантической структуры слов с диффузным значением (на материале ассоциативного эксперимента со словами-синонимами русского языка) // Вестник Томского государственного университета. № 351. С. 19-21.

Копотев М., 2014. Введение в корпусную лингвистику. Прага : Animedia Company. 230 c.

Лазуренко Е. Ю., Саломатина М. С., Стернин И. А., 2007. Профессиональная коммуникативная личность. Воронеж : Истоки. 194 с.

Лебедева С. В., 2002. Синонимы или проксонимы? Курск : Изд-во Кур. гос. пед. ун-та. 201 с.

Леонтьев А. А., 1997. Основы психолингвистики. М. : Смысл. $287 \mathrm{c}$.

Лукашевич Н. В., 2011. Тезаурусы в задачах информационного поиска. М. : Изд-во МГУ. 512 с.

Нистратов А. А., Тарасов Е. Ф., 2017. Психосемантический эксперимент как инструмент анализа смысла и значения слова // Вопросы психолингвистики. № 2. С. 124-134. 
Ольховская А. И., 2017. Проблема синонимии в аспекте идеографического описания лексики // Русский язык в поликультурном мире: I Международный симпозиум (8-12 июня 2017 г., г. Ялта) : сб. науч. ст. : 2 т. / отв. ред. Е. Я. Титаренко. Симферополь : АРИАЛ. Т. 2 C. 96-102.

Петренко В. Ф., 2009. Многомерное сознание - психосемантическая парадигма. М. : Новый хронограф. 440 с.

Порождение тезауруса типа WordNet для русского языка, 2016 / Н. В. Лукашевич, Г. Лашевич, А. А. Герасимова, В. В. Иванов, Б. В. Добров // Пятнадцатая национальная конференция по искусственному интеллекту с международным участием КИИ-2016 (3-7 октября 2016 г., г. Смоленск) : тр. конф. : в 3 т. Смоленск : [б. и.]. T. 2. C. 89-97.

Erofeeva I. V., Gimatova L. I., Sergeeva E. V., 2018. Modeling of the Lexico-Semantic Field «Intellect» in the Russian Translation of Herman Hesse's Novel Steppenwolf // Modern Journal of Language Teaching Methods. Vol. 8, iss. 9. P. 54-59.

Janda L. A., Solovyev V. D., 2009. What Constructional Profiles Reveal About Synonymy: A Case Study of Russian Words for SADNESS and HAPPINESS // Cognitive Linguistics. Vol. 20, iss. 2. P. 367-393.

McEnery T., Hardie A., 2011. Corpus Linguistics: Method, Theory and Practice. Cambridge : Cambridge University Press. 292 p.

\section{ИСТОЧНИКИ И СЛОВАРИ}

Абрамов - Абрамов Н. Словарь русских синонимов и сходных по смыслу выражений. М. : Русские словари, 1999. 433 с.

Кожевников - Кожевников А. Ю. Большой синонимический словарь русского языка: речевые эквиваленты: практический справочник : в 2 т. СПб. : Нева, 2003. Т. 1. 437 с. ; Т. 2. 476 с.

Ожегов, Шведова - Ожегов С. И., Шведова Н. Ю. Толковый онлайн-словарь русского языка. 1999. URL: https://lexicography.online/ explanatory/ozhegov (дата обращения: 29.05.2019)

Словарь синонимов - Словарь синонимов русского языка / под общ. ред. Л. Г. Бабенко. М. : Астрель : АСТ, 2011. 688 с.

Словарь синонимов русского языка - Словарь синонимов русского языка / Л. П. Алекторова, Л. А. Введенская, В. И. Зимин, О. М. Ким, Н. П. Колесников, В. Н. Шанский. М. : Астрель, 2002.336 c.
Александрова 3. Е. Словарь синонимов русского языка / под ред. Л. А. Чешко. М. : Сов. энцикл., 1969.600 с.

Горбачевич К. С. Краткий словарь синонимов русского языка. М. : Астрель, 2003. 605 с.

Новый объяснительный словарь синонимов русского языка / под общ. рук. акад. Ю. Д. Апресяна. М. ; Вена : Яз. слав. культуры, 2004. 1488 с.

Словарь синонимов русского языка : в 2 т. / под ред. А. П. Евгеньевой. М. : Астрель, 2003. Т. 1. 680 c. ; Т. 2.856 c.

Tезаурус русского языка RuWordNet. URL: https:// ruwordnet.ru/ru (дата обращения 27.06.2019)

\section{REFERENCES}

Artemyeva E.Yu., 1999. Osnovy psikhologii subyektivnoy semantiki [Fundamentals of the Psychology of Subjective Semantics]. Moscow, Nauka Publ., Smysl Publ. 349 p.

Gutner G.B. Sinonimiya [Synonymy]. Gumanitarnaya entsiklopediya: Kontsepty [Humanitarian Encyclopedia: Concepts]. URL: https://gtmarket. ru/concepts/7061 (accessed 29 May 2019).

Dudareva Ya.A., 2011. Osobennosti semanticheskoy struktury slov s diffuznym znacheniem (na materiale assotsiativnogo eksperimenta so slovami-sinonimami russkogo yazyka) [Semantic Structure of Words with Diffusive Meanings (Based on an Associative Experiment with Synonyms of the Russian Language)]. Vestnik Tomskogo gosudarstvennogo universiteta [Tomsk State University Journal], no. 351, pp. 19-21.

Kopotev M., 2014. Vvedenie v korpusnuyu lingvistiku [Introduction to Corpus Linguistics]. Praga, Animedia Company. $230 \mathrm{p}$.

Lazurenko E.Yu., Salomatina M.S., Sternin I.A., 2007. Professionalnaya kommunikativnaya lichnost [Professional Communicative Personality]. Voronezh, Istoki Publ. 194 p.

Lebedeva S.V., 2002. Sinonimy ili proksonimy? [Synonyms or Proxy Names?] Kursk, Izd-vo Kurskogo gosudarstvennogo pedagogicheskogo universiteta. $201 \mathrm{p}$.

Leontyev A.A., 1997. Osnovy psikholingvistiki [Fundamentals of Psycholinguistics]. Moscow, Smysl Publ. 287 p.

Lukashevich N.V., 2011. Tezaurusy v zadachakh informatsionnogo poiska [Thesauruses in Information Retrieval Tasks]. Moscow, Izd-vo MGU. 512 p.

NistratovA.A., Tarasov E.F., 2017. Psikhosemanticheskiy eksperiment kak instrument analiza smysla i znacheniya slova [Psychosemantic Experiment as a Tool for Analyzing the Meaning and Meaning of a Word]. Voprosy 
psikholingvistiki [Journal of Psycholinguistics], no. 2, pp. 124-134.

Olkhovskaya A.I., 2017. Problema sinonimii v aspekte ideograficheskogo opisaniya leksiki [The Problem of Synonymy in the Aspect of Ideographic Description of the Vocabulary]. Titarenko E.Ya., ed. Russkiy yazyk v polikulturnom mire: I Mezhdunarodnyy simpozium (8-12 iyunya 2017 g., g. Yalta): sb. nauch. st.: $v 2 t$. [Russian Language in the Multicultural World. $1^{\text {st }}$ International Symposium (June 8-12, 2017, Yalta). Collection of Scientific Articles. In 2 Vols.]. Simferopol, ARIAL, vol. 2, pp. 96-102.

Petrenko V.F., 2009. Mnogomernoe soznanie psikhosemanticheskaya paradigma [Multidimensional Consciousness Psychosemantic Paradigm]. Moscow, Novyy khronograf Publ. 440 p.

Lukashevich N.V., Lashevich G., Gerasimova A.A., Ivanov V.V., Dobrov B.V., 2016. Porozhdenie tezaurusa tipa WordNet dlya russkogo yazyka [Generating Russian WordNet]. Pyatnadtsataya natsionalnaya konferentsiya po iskusstvennomu intellektu s mezhdunarodnym uchastiem KII-2016 (3-7 oktyabrya 2016 g., g. Smolensk): trudy konferentsii: $3 t$. [Fifteenth National Conference on Artificial Intelligence with International Participation CAI-2016 (October 3-7, 2016, Smolensk, Russia). Proceedings of the Conference: 3 Vols.]. Smolensk, vol. 2, pp. 89-97.

Erofeeva I.V., Gimatova L.I., Sergeeva E.V., 2018. Modeling of the Lexico-Semantic Field "Intellect" in the Russian Translation of Herman Hesse's Novel Steppenwolf. Modern Journal of Language Teaching Methods, vol. 8, iss. 9, pp. 55-59.

Janda L.A., Solovyev V.D., 2009. What Constructional Profiles Reveal About Synonymy: A Case Study of Russian Words for SADNESS and HAPPINESS. Cognitive Linguistics, vol. 20, iss. 2, pp. 367-393.

McEnery T., Hardie A., 2011. Corpus Linguistics: Method, Theory and Practice. Cambridge University Press. 292 p.

\section{SOURCES AND DICTIONARIES}

Abramov N. Slovar russkikh sinonimov i skhodnykh po smyslu vyrazheniy [Dictionary of Russian Synonyms and Similar Expressions]. Moscow, Russkie slovari Publ., 1999. 433 p.

Kozhevnikov A.Yu. Bolshoy sinonimicheskiy slovar russkogo yazyka: rechevye ekvivalenty: prakticheskiy spravochnik: $v 2 t$. [Large Synonymic Dictionary of the Russian Language: Speech Equivalents. Practical Reference. In 2 Vols.] Saint Petersburg, Neva Publ., 2003, vol. 1. 437 p., vol. 2, 476 p.

Ozhegov S.I., Shvedova N.Yu. Tolkovyy onlayn-slovar russkogo yazyka [Explanatory Online Dictionary of the Russian Language], 1999. URL: https:// lexicography.online/explanatory/ozhegov/ (accessed 29 May 2019).

Babenko L.G., ed. Slovar sinonimov russkogo yazyka [Dictionary of Synonyms of the Russian Language]. Moscow, Astrel Publ., AST Publ., $2011.688 \mathrm{p}$.

Alektorova L.P., Vvedenskaya L.A., Zimin V.I., Kim O.M., Kolesnikov N.P., Shanskiy V.N., eds. Slovar sinonimov russkogo yazyka [Dictionary of Synonyms of the Russian Language]. Moscow, Astrel Publ., 2002. 336 p.

Aleksandrova Z.E. Slovar sinonimov russkogo yazyka [Dictionary of Synonyms of the Russian Language]. Moscow, Sovetskaya entsiklopediya Publ., 1969. 600 p.

Gorbachevich K.S. Kratkiy slovar sinonimov russkogo yazyka [Brief Dictionary of Synonyms of the Russian Language]. Moscow, Astrel Publ., 2003. $605 \mathrm{p}$.

Apresyan Yu.D., ed. Novyy obyyasnitelnyy slovar sinonimov russkogo yazyka [New Explanatory Dictionary of Russian Synonyms]. Moscow, Vena, Yazyki slavyanskoy kultury Publ., 2004. 1488 p.

Evgenyeva M., ed. Slovar sinonimov russkogo yazyka: $v 2 t$. [Dictionary of Synonyms of the Russian Language. In 2 Vols.]. Moscow, Astrel Publ., 2003, vol. 1, 680 p., vol. 2, 856 p.

Thesaurus of Russian Language RuWordNet. URL: https://ruwordnet.ru/ru (accessed 27 June 2019). 


\section{Information About the Authors}

Irina V. Erofeeva, Doctor of Sciences (Philology), Professor, Department of the Russian Language and Methods of Teaching, Kazan Federal University, Kremlevskaya St., 18, 420008 Kazan, Russia, erofeeva89@mail.ru, https://orcid.org/0000-0002-6702-9129

Valery D. Solovyev, Doctor of Sciences (Physics and Mathematics), Professor, Chief Researcher, Kazan Federal University, Kremlevskaya St., 18, 420008 Kazan, Russia, maki.solovyev@mail.ru, https://orcid.org/0000-0003-4692-2564

Venera R. Bajrasheva, Candidate of Sciences (Physics and Mathematics), Associate Professor, Department of Theoretical Cybernetics, Kazan Federal University, Kremlevskaya St., 18, 420008 Kazan, Russia, vbayrasheva@gmail.com, https://orcid.org/0000-0002-1728-034X

\section{Информация об авторах}

Ирина Валерьевна Ерофеева, доктор филологических наук, профессор кафедры русского языка и методики его преподавания, Казанский федеральный университет, ул. Кремлевская, 18, 420008 г. Казань, Россия, erofeeva89@mail.ru, https://orcid.org/0000-0002-6702-9129

Валерий Дмитриевич Соловьев, доктор физико-математических наук, профессор, главный научный сотрудник, Казанский федеральный университет, ул. Кремлевская, 18, 420008 г. Казань, Россия, maki.solovyev@mail.ru, https://orcid.org/0000-0003-4692-2564

Венера Рустамовна Байрашева, кандидат физико-математических наук, доцент кафедры теоретической кибернетики, Казанский федеральный университет, ул. Кремлевская, 18, 420008 г. Казань, Россия, vbayrasheva@gmail.com, https://orcid.org/0000-0002-1728-034X 